\title{
Implementing plant biostimulants and biocontrol strategies in the agroecological management of cultivated ecosystems. A review
}

\author{
Geraldine Le Mire ${ }^{(1,2)^{*}}$, Minh Luan $\operatorname{Nguyen}^{(1,3)^{*}}$, Berenice Fassotte ${ }^{(1,4)}$, \\ Patrick du Jardin ${ }^{(3)}$, François Verheggen ${ }^{(4)}$, Pierre Delaplace ${ }^{(3)^{* * *}}$, M. Haissam Jijakli ${ }^{(2)^{* *}}$ \\ (1) University of Liège - Gembloux Agro-Bio Tech. TERRA. AgricultureIsLife. Passage des Déportés, 2. BE-5030 Gembloux \\ (Belgium).E-mail: geraldine.lemire@ulg.ac.be \\ (2) University of Liège - Gembloux Agro-Bio Tech. Agrobiochem. Urban and Integrated Phytopathology. Passage des \\ Déportés, 2. BE-5030 Gembloux (Belgium). \\ (3) University of Liège - Gembloux Agro-Bio Tech. Agrobiochem. Plant Biology. Passage des Déportés, 2. BE-5030 \\ Gembloux (Belgium). \\ (4) University of Liège - Gembloux Agro-Bio Tech. Agrobiochem. Functional and Evolutionary Entomology. Passage des \\ Déportés, 2. BE-5030 Gembloux (Belgium). \\ * These authors contributed equally to this work. ** Co-last authors.
}

Received on April 1, 2015; accepted on October 14, 2015.

Introduction. In the context of sustainable agricultural production, agroecology aims at optimizing the economic and environmental performances of beneficial ecosystem services in order to (i) increase the productivity and resilience of cultivated ecosystems and (ii) preserve their natural resources. The maintenance of such performances is supported by research via the development of new tools that enhance plant tolerance to numerous biotic and abiotic stresses.

Literature. Biostimulants can be used as a tool to complement the use of chemical inputs, by involving non-living-based products, or living-based products containing beneficial rhizosphere microbiome, such as plant growth-promoting rhizobacteria (PGPR). Pest management research has also made major advances in the development of efficient biocontrol methods. Elicitors and semiochemicals are considered to be some of the most promising tools for inducing plant resistance to various diseases and enhancing natural predation, respectively. Several products are already on the market. This review discusses current methods for exploiting and applying biostimulant and biocontrol products in contemporary agricultural systems. Future applications of these tools for sustainable management of cultivated ecosystems are also discussed.

Conclusions. These tools are still difficult to use because of their lack of reliability in the field and their uneasy integration in the cropping systems. Further studies are needed to better understand the parameters influencing the efficiency of PGPR, elicitors and semiochemicals. Special attention needs to be given to the formulation and the interactions of these products with plant physiology and the environment.

Keywords. Agroecology, biological control, plant growth stimulants, biofertilizers, biopesticides, induced resistance, rhizobacteria, semiochemicals, elicitors.

Intégrer les biostimulants et les stratégies de biocontrôle dans la gestion agroécologique des écosystèmes cultivés (synthèse bibliographique)

Introduction. Dans le cadre d'une production agricole durable, l'agroécologie vise à optimiser les performances économiques et environnementales des services écosystémiques avantageux afin d'assurer (i) une augmentation en productivité et en résilience des écosystèmes cultivés et (ii) une préservation de leurs ressources naturelles. Le maintien de ces performances est soutenu par la recherche via le développement de nouveaux outils permettant d'augmenter la tolérance des plantes aux stress biotiques et abiotiques.

Littérature. Les biostimulants peuvent être utilisés comme un outil complémentaire à l'utilisation d'intrants chimiques via l'usage de formulations inertes ou vivantes contenant des microbiontes rhizosphériques bénéfiques tels que les bactéries promotrices de la croissance des plantes (PGPR). La recherche en phytopathologie a également fait des progrès conséquents dans le développement de méthodes de lutte. Les éliciteurs et sémiochimiques font partie des outils de biocontrôle les plus 
prometteurs en stimulant, respectivement, les défenses naturelles des plantes contre de nombreuses maladies et la prédation naturelle. Plusieurs produits sont déjà disponibles sur le marché. Cette synthèse décrit les méthodes actuelles d'emploi et d'application des produits biostimulants et de biocontrôle dans les systèmes agricoles actuels. Le futur de ces techniques dans la gestion durable des écosystèmes cultivés est également abordé. Conclusions. Ces outils sont encore difficilement utilisables du fait de leur efficacité variable au champ et du manque de recul sur la manière de les intégrer dans les systèmes de culture. Des recherches supplémentaires sont nécessaires afin de mieux comprendre les paramètres conditionnant l'efficacité des PGPR, des éliciteurs et des sémiochimiques. L'accent doit être porté sur la formulation et les interactions de ces produits avec la physiologie et l'environnement de la plante.

Mots-clés. Agroécologie, lutte biologique, stimulant de croissance végétale, biofertilisants, biopesticide, résistance induite, rhizobactérie, substance sémiochimique, éliciteur.

\section{INTRODUCTION}

The decline in natural resources and the environmental damage inflicted by current agricultural practices have become major limitations in conventional agriculture. Against this background, agroecology offers an important scientific approach that takes into account the current societal concerns linked to agriculture, economy and, in particular, the environment. By using ecological principles, it aims at studying and designing agricultural systems based on the interactions of their main biophysical, technical and socioeconomic components (European Commission, 2012). Research is now strongly focused on the use of agroecological principles to minimize potentially harmful chemical inputs and manage ecological relationships and agrobiodiversity. The past decade has seen the emergence of technological tools developed to promote sustainable agroecosystems. The enhancement of plant tolerance to numerous abiotic stresses is increasingly being supported by biostimulant products, as preferred alternatives to chemical fertilizers. Biostimulants include living microorganisms, namely plant growthpromoting fungi (PGPF) and rhizobacteria (PGPR) (Bhattacharyya et al., 2012). Plant growth-promoting rhizobacteria are currently thought to be an effective tool for the biostimulation of plant growth (Calvo et al., 2014). Beneficial rhizobacteria associate with the root system and stimulate the growth of host plants, while being fed in turn by root exudates. Pest management researchers have also made major advances in the development of efficient biocontrol methods to protect plants against biotic stresses. Biocontrol refers to any method, product or organism using natural mechanisms in the context of integrated crop protection against bioaggressors (Herth, 2011). Biocontrol products include macro- and microorganisms, natural substances of plant, mineral or animal origin, and chemical mediators. Elicitors (also called plant resistance inducers) are considered to be biocontrol products in agriculture as they induce plant resistance to various diseases. Similarly, semiochemicals are seen as biocontrol tools because they involve push-pull strategies and/or mating disruptions.
This paper gives an overview of the present status of these tools in agricultural production, as well as a description of the modes of action of PGPR biostimulants, elicitors and semiochemicals. It then addresses the question of how and why future strategies should increase the use of these tools by highlighting both their limitations and their potential for contributing to sustainable and agroecological agriculture.

\section{BIOSTIMULANT AND BIOCONTROL TOOLS IN CONVENTIONAL AGRICULTURE}

The development of new green technologies has led to greater research focus on biostimulant and biocontrol tools (Boller et al., 2009; Bhattacharyya et al., 2012). The definition and modes of action of three tools PGPR, elicitors and semiochemicals - are described in this chapter.

\subsection{PGPR-based biostimulants}

The sustainable management of soil fertility is a major concern given the adverse impact and ecological threats posed by the use of conventional chemical fertilizers (Wezel et al., 2014). In this context, biostimulants represent an interesting alternative. They consist of various substances and microorganisms (microbial inoculants, humic and fulvic acids, seaweed extracts, protein hydrolysates, amino acids), which are used to enhance plant growth (du Jardin, 2012; Calvo et al., 2014). They can increase crop yield by at least 5-10\% and improve fertilizer use efficiency by at least $5-25 \%$ (European Biostimulants Industry Consortium, 2011). In 2012, the global market of biostimulants was mainly located in Europe and it is projected to increase by $12 \%$ annually, reaching $\$ 2,241$ million by 2018 (Calvo et al., 2014).

Despite their growing use, there is currently no accepted definition of biostimulants, neither by regulatory bodies nor by the scientific community. However, with the revision of current European Union (EU) legislation on fertilizers, there has been some progress. Within this framework, a consultancy report 
defined a plant biostimulant as "any substance or microorganism, in the form in which it is supplied to the user, applied to plants, seeds or the root environment with the intention to stimulate natural processes of plants benefiting nutrient use efficiency and/or tolerance to abiotic stress, regardless of its nutrients content, or any combination of such substances and/ or microorganisms intended for this use" (Traon et al., 2014). This definition clearly differentiates biostimulants from biocontrol substances or agents.

In this review, we focus on biostimulants in the category of microbial inoculants, specifically PGPR, which have been intensively studied in recent decades (Calvo et al., 2014). Plant growth-promoting rhizobacteria-based biostimulants are major components of biofertilizers intended for agricultural use. They have long been commercialized by many manufacturers and applied to various field crops such as rice, wheat, maize and soybean (Köhl, 2010; Pérez-Montaño et al., 2013), as well as to horticultural crops such as tropical, subtropical and temperate fruits and vegetables (Reddy, 2014).

Plant growth-promoting rhizobacteria-based biostimulants are considered to be easy-to-use agroecological tools for stimulating plant growth and enhancing plant nutrient uptake and abiotic stress tolerance (Walker et al., 2012; Hol et al., 2013; Pérez-Montaño et al., 2013). They can also enhance beneficial symbioses with the host plant. Some PGPRbased biostimulants also have a biocontrol activity, enabling them to protect plants against biotic stresses (Bhattacharyya et al., 2012). This activity, however, is not discussed in this review.

Biostimulant products can be based on a single PGPR strain, a PGPR mix or a mix of PGPR and PGPF. Compared with single strain products, consortia can reach most of the empty niches because of their increased genetic diversity and they colonize the root zone much faster than single strains (Reddy, 2014). Products with a mix of PGPR strains can therefore compete spatially with a broader range of potential pathogens under different plant growth and environmental conditions (Reddy, 2014). In addition, recent studies have shown that PGPR used to complement mineral fertilization can reduce conventional fertilizer rates (Adesemoye et al., 2009). Adesemoye et al. (2009) showed that a combined inoculation of the two PGPR strains Bacillus amyloliquefaciens IN937a and Bacillus pumilus $\mathrm{T} 4$ with a strain of the arbuscular mycorrhiza fungi Glomus intraradices reduced fertilizer use by $25 \%$. This combination was as efficient as a $100 \%$ fertilizer application in terms of plant growth, yield, and nutrient uptake. Other examples of PGPR-based biostimulants that enhance crop growth and reduce the amount of needed chemical fertilizers are given in appendix 1.
The capacity of PGPR to stimulate plant growth relies mainly on their capacity to produce/degrade various plant-growth regulators. Phytohormones (e.g. auxins, cytokinins, gibberellins, ethylene) produced by PGPR can regulate multiple plant physiological processes (root initiation and elongation, root hair formation) (Calvo et al., 2014). For example, rhizosphere bacteria such as Azospirillum, Bacillus, Rhizobium and Enterobacter can reduce the production of the plant stress hormone ethylene via the secretion of 1-amino cyclopropane-1-carboxylate deaminase, thus preventing plant growth inhibition (Bhattacharyya et al., 2012).

Plant growth-promoting rhizobacteria can also increase the availability of nutrients for the host plant. The mechanisms involved include nitrogen $(\mathrm{N})$ fixation, nutrient solubilization, PGPR production of volatile organic compounds (VOCs), and iron sequestering by PGPR-produced siderophores (Bhattacharyya et al., 2012; Calvo et al., 2014). Less than half (10-40\%) of the applied nitrogen in the field is effectively absorbed by plants, and 60-90\% of chemical $\mathrm{N}$ fertilizers are generally lost by nitrate leaching or ammonia volatilization. Nitrogen fertilizer is transformed into ammonia gases, including nitrous oxide $\left(\mathrm{N}_{2} \mathrm{O}\right)$, a major greenhouse gas (Adesemoye et al., 2009). Such N-loss processes can result in water and soil pollution and/ or greenhouse-gas generation. Plant growth-promoting rhizobacteria used to complement mineral fertilizers can help solve these issues (Calvo et al., 2014). Finally, PGPR inoculants can also enhance crop tolerance to salinity and drought, notably by reducing soil 1-amino cyclopropane-1-carboxylate deaminase (ACC) and pollutants (herbicides, pesticides, heavy metal detoxification) (Upadhyay et al., 2015).

There is therefore growing scientific evidence supporting the use of PGPR inoculants as biofertilizers for many plants. For example, FZB24® was shown to promote plant growth and yield in cotton, tomato and maize (Kilian et al., 2000; Yao et al., 2006). Similarly, RhizoVital42@ proved efficient in lettuce (Chowdhury et al., 2013; Kröber et al., 2014), BactofilA10® in rye-grass (Tállai et al., 2012), and TwinN ${ }^{\circledR}$ in sugarcane (Simwinga et al., 2010). Further information on commercialized PGPR products are given in appendix 2.

Products containing exogenous PGPR compounds (e.g. exopolysaccharides, phytohormones) have also been developed to enhance the growth of specific beneficial microbes in the soil (Marks et al., 2013). The efficiency of PGPR-based products, however, still relies on several factors. Plant species and variety (releasing different types of root exudates), soil type, environmental conditions, and the commercial formulation are crucial determinants of the efficient and reproducible action of inoculated PGPR (Calvo 
et al., 2014). The best PGPR products generally consist of local strains that are specific to the host plant, show good capacity for physiological and genetic adaptation and co-evolve with other native strains in a common habitat (Reddy et al., 1999; Mäder et al., 2011; Araújo et al., 2013).

\subsection{Biocontrol products and crop protection}

Elicitors. In the late 1970s, it was discovered that plants have inducible defense mechanisms that are activated by infection and could potentially provide protection against a broad spectrum of pathogens (Schwessinger et al., 2012). This resistance is triggered by the plant when it senses "non-self" molecules released during the attack, known as general elicitors. The term "elicitor" refers to all the signal molecules that are perceived and that induce a defensive reaction in the plant. They therefore play a key role in plant-pathogen interactions (Vallad et al., 2004).

Induced resistance has long been recognized as a valuable approach in disease control strategies because it offers the promise of durable, broad-spectrum disease control using the plant's own resistance (Walters et al., 2014). The elicitor products currently in the marketplace are used mainly in integrated pest management (IPM) strategies as complementary tools to help reduce chemical inputs. Until now and depending on their efficiency, elicitors are usually applied alone or in combination with other fungicides, once or several times in a crop cycle (Walters et al., 2013). Additional information on currently commercialized elicitor products are given in appendix 3 .

Two well-known elicitor products are the algae extract laminarin, and benzo-(1, 2, 3)-thiadiazole7-carbothioic acid S-methyl ester (BTH, also known as BION® from Syngenta Europe) (Sobhy et al., 2012). BION ${ }^{\circledR}$, however, is a chemical elicitor (with a structural analogy to the plant hormone salicylic acid) and can therefore be excluded from the category of biocontrol products, defined by Herth (2011) as "agents or products which use natural mechanisms in the frame of an integrated pest management (IPM). This includes macro-organisms (insects, nematodes), micro-organisms (bacteria, fungi, viruses), chemical mediators (pheromones, kairomones), and natural substances of plant, animal or mineral origin." This review follows this definition.

Some elicitor products are also suitable for organic farming, which has surged in popularity in recent years (Dayan et al., 2009). Organic practices prohibit the use of synthetic chemical products and therefore have to address important disease pressures because of the lack of pesticide applications. For acceptance in organic agriculture, the elicitor compounds should occur in nature and should not be derived from genetically modified organisms (García-Mier et al., 2013). For example, laminarin is considered to be suitable for organic farming, and plant protection products that contain it are registered in Belgium, Greece, France, The Netherlands, the UK and Germany (European Commission EGTOP, 2011).

There has been an intense hunt for elicitors since the discovery of interesting ones that could be used for agricultural purposes. Three categories of elicitors have been determined so far: pathogen-associated molecular patterns (PAMPs) emitted specifically from pathogenic organisms or parasites; microbe-associated molecular patterns (MAMPs), overall released by beneficial/ non-pathogenic microorganisms such as yeasts, and plant growth-promoting rhizobacteria or plant growthpromoting fungi; endogenous molecular patterns related to injured plant tissue (DAMPs, for damage- or danger-associated molecular patterns) emitted from the plant itself (Henry et al., 2012). These danger-signaling compounds are essential components of entire classes of microorganisms and have been shown to protect a variety of plants against a broad spectrum of pathogens (Schwessinger et al., 2012). Non-microbial elicitors have also been identified, originating from an array of organic sources, such as algae extracts, crustacean shells and minerals, as well as from chemical synthesis (Henry et al., 2012). The various signaling pathways these three elicitor categories trigger in plants are described in appendix 4. Most of the organic elicitors that have been characterized include fungal chitin, bacterial flagellin, lipopolysaccharides (LPS), oligogalacturonides (OGAs), ergosterol, siderophores, surfactin and fengycin cyclic lipopeptides, and volatile organic compounds (VOCs).

Elicitor perception activates the plant's immune system which is characterized by a cascade of events with a complex spatial and temporal regulation. This includes a local burst of reactive oxygen species (ROS), ion fluxes across the plasma membrane, and the production of phytoalexins and pathogenesisrelated (PR) proteins (Henry, 2013). At the scale of the whole plant, elicitor perception triggers specific signal transduction pathways involving one or several key regulators, and resulting in one of two possible forms of induced resistance: systemic acquired resistance (SAR) against biotrophic and hemibiotrophic pathogens, combined with a characteristic accumulation of PR proteins; or induced systemic resistance (ISR) against necrotrophic pathogens, chewing herbivores and phloem-feeding insects (Henry et al., 2012; Wasternack et al., 2013). Depending on the plant and the elicitor, a set period of time is required for systemic resistance to be embedded.

In addition, some elicitors can trigger a process called priming, which prepares the plant for a faster and stronger resistance only when a subsequent pathogen 
attack occurs (Walters et al., 2014). Priming is more cost-effective than elicitation because the energy cost of induced resistance in the plant is optimized (Beckers et al., 2007). Although the molecular mechanisms behind priming remain poorly understood, some natural and synthetic compounds have demonstrated good priming-inducing activity in laboratory and field conditions, such as the nonprotein $\beta$-aminobutyric acid (BABA) (Walters et al., 2014). The diversity of defense mechanisms and signaling pathways involved in induced resistance underline the potential use of elicitors in plant protection. Since the first discovery of elicitors about 20 years ago, research on these specific compounds and their mode of action has considerably increased understanding of the plant immune system and opens the way to the development of new tools for disease management strategies (Schwessinger et al., 2012).

Semiochemicals. Living organisms emit a range of semiochemicals, i.e. molecules that act as messengers and induce behavioral or physiological responses in other individuals. They are usually classified into two groups depending on the trophic levels concerned: intraspecific (pheromones) or interspecific (allelochemicals) (Vet et al., 1992).

Semiochemicals are a promising alternative to insecticides as they are highly specific, slightly toxic or non-toxic molecules, and are safe for the environment. In agroecosystems, pest control with semiochemicals is based on exploiting methods to chemically increase, conserve and enhance the efficacy of natural predation (Rodriguez-Saona et al., 2012). Push-pull strategies use a combination of stimuli that manipulate the behavior of insect pests and/or natural enemies in order to alter their abundance and distribution in agroecosystems (Cook et al., 2007). This approach is based on repellent or deterrent chemical stimuli that push insect pests away from the crop. At the same time, they are attracted by highly attractive stimuli coming from traps or from trap crops where they can be easily controlled (Cook et al., 2007). Each agricultural system needs to develop an appropriate and unique push-pull strategy based on a good understanding of the targeted pest's biology and its interactions with its hosts and natural enemies (Khan et al., 2004). One example of a successful pushpull strategy was conducted in Africa against stem borers in maize and sorghum (Khan et al., 2001).

Another successful application of semiochemicals for direct pest control involves mating disruption, whereby sex pheromones are applied in crops, saturating the environment in order to confuse males and interfere with mating behavior. Females fail to mate and thus the number of fertilized eggs and larvae is reduced and there is a decrease in pest populations. This technique is being applied worldwide against moths in orchards, vegetable crops and forestry (Cardé, 2007).

Currently, Isomate ${ }^{\circledR}$ dispensers (Shin-Etsu Chemical Co. Ltd.), which consist of polyethylenetubes loaded with pheromones, are the most common dispensers in orchards (Rodriguez-Saona et al., 2009). In recent years, interest in methyl salicylate (MeSA) has grown because of its capacity to attract natural enemies in cultivated fields. This volatile compound is produced in several plant species and is emitted in response to pest attacks (Pichersky et al., 2002). Recent research studies have demonstrated the attractive effect of MeSA on natural enemies such as coccinellids, syrphids, lacewings, predatory bugs and some parasitic Hymenoptera (Rodriguez-Saona et al., 2011). In the USA, a commercial product containing MeSA as an active substance is sold as PredaLure ${ }^{\circledR}$ (AgBio Inc., Westminster, Colorado, USA).

\section{IMPLEMENTATION CHALLENGES IN AGRICULTURAL PRACTICES}

The literature supports the implementation of biostimulant and biocontrol tools in agroecological practices, with clear demonstrations of their potential to reduce chemical inputs, save energy and provide farmers with new opportunities for sustainable fertilization and disease control (Mejía-Teniente et al., 2010; Chandler et al., 2011; Calvo et al., 2014; Wezel et al., 2014). The agroecological use of these tools will obviously require a shift in conventional practices from total reliance on pesticides and fertilizers to the integrated management of biotic and abiotic stresses (Vallad et al., 2004; Wezel et al., 2014). However, biostimulant and biocontrol products are not yet used as routine tools in agriculture. In the second half of this review, we explain the drawbacks restricting the widespread use of PGPR, elicitors and semiochemicals in agriculture, and what is being developed to enhance their use, and thus make an important contribution to the agroecological and sustainable management of cultivated ecosystems.

\subsection{Screening biostimulant and biocontrol products}

The screening of suitable PGPR inoculants, elicitors and semiochemicals for specific crops, growth conditions and pathogens is critical if the efficacy of these products in the field is to be guaranteed. A common method for screening an effective PGPR inoculant is to isolate strains from plant growth-promoting soil or from pathogen-suppressive soil (Mendes et al., 2011). Screening failures can occur, as some PGPR strains which show limited ability to promote plant growth 
during screening trials under controlled conditions can be among the most effective strains in the field (Araújo et al., 2013). Such results could be due to the differences between field and controlled conditions, and it appears that PGPR, which increase the nutrient uptake capacity of roots in a large field, cannot express such properties easily in vitro or in small-scale pots. In addition, the screening of multiple microbes in consortia is complicated and requires considerable time and research, as well as knowledge of microbial ecology and of the interactions between the strains of a biostimulant product, the host plant and the local rhizomicrobial community. Recent progress in molecular biology and biotechnology will probably facilitate PGPR screening (Bhattacharyya et al., 2012).

Similarly, the screening of elicitors is usually done under controlled conditions initially, before being done in the field. Screening protocols are adapted to a targeted disease and to the plant to be protected. Different plant genotypes showing various levels of susceptibility to the disease can be used, as well as one or several infectious strains of the pathogen. The amount and positioning of the elicitors need to be optimized, as does the mode of application, the number of treatments and the plant development stage (Walters et al., 2013). The next step is to investigate the signaling pathways involved in the elicitation process using various methods, such as biochemical studies measuring the amount of plant defenserelated compounds (plant hormones, phytoalexins, enzymatic activity, ROS) or molecular biology studies measuring the expression of genes associated with plant defense mechanisms (Walters et al., 2014). The final step involves investigating the influence of various environmental parameters (temperature, relative humidity, luminosity) for subsequent field trials (Walters et al., 2014).

\subsection{Formulation and application methods}

The formulation and application method are probably among the most critical parameters determining the efficiency of biostimulant and biocontrol products. The formulation must maintain an effective plantgrowth promotion or biocontrol capacity and be easy to use (Bashan et al., 2014; Walters et al., 2014). In the case of PGPR inoculants, Bashan et al. (2014) summarized various formulation methods, from the choice of carriers (peat, coir dust, charcoal, sawdust, clay, perlite, vermiculite, polymer-like alginate) to the formulation process. They also summarized various practical techniques for inoculant application and production achievement. Seed treatment has attracted attention as a simple and economically viable technique, being convenient for both farmers and industry (Bashan et al., 2014). The seeds are usually coated with a carrier and PGPR, with or without adhesives (carboxymethyl cellulose, sucrose, vegetable oil, Arabic gum). This is currently the method most often used to apply PGPR inoculants as it ensures an optimal threshold number of PGPR cells per seed needed to cover the seedling roots. Although the cell threshold differs among strains, the common concentration is $10^{8}$ cells per plant (Bhattacharyya et al., 2012). Soil applications of PGPR are performed when a large population of rhizobacteria is needed at a specific and crucial plant growth stage (e.g. tillering or flowering stages) (Bashan et al., 2014). However, soil and openair conditions (humidity, temperature) can affect the success of the soil application. Extreme temperatures can cause a decline in the PGPR survival rate, and soil humidity determines the effective mobility of the inoculated bacteria in the rhizosphere (Bashan et al., 2014). Using enough water (e.g. at least $\left.1001 \cdot \mathrm{ha}^{-1}\right)$ in the mixture with liquid or powder-based inoculants also ensures that the bacteria are positioned near the root system. Additional PGPR inoculations could be needed to maintain a minimal bacteria population in the case of stressful conditions such as winter and drought (Bashan et al., 2014).

In contrast, commercialized elicitor products are usually applied as a topical spray, once or several times in the season, to complement fungicide treatments (Walters et al., 2014). Worral et al. (2012) demonstrated that seeds are also receptive to plant elicitors such as jasmonic acid or $\beta$-aminobutyric acid (BABA), thereby triggering long-lasting protection against a wide spectrum of pathogens. Seed treatments using elicitors represent a promising technique in pest management for sustainable agriculture, but more research is needed to understand the benefits and costs of the application methods. Soil drench applications of elicitors have recently been reported to achieve good results (Walters et al., 2014).

Finally, semiochemicals do have some limitations, linked to their volatile nature, but significant advances and new applications are expected in the coming years. The formulation should therefore ensure a controlled release of semiochemicals over time. Ideally, slowrelease devices should meet particular specifications, such as sufficiently high aerial concentrations for detection, reproducibility in terms of dispenser production and efficiency over a given time span (Heuskin et al., 2011). Dispensers should be applied early in the growing season, when pest populations are quite low, because the release rate of most dispensers tends to decrease with time (Witzgall, 2001). In terms of efficacy, the optimal concentration and density of semiochemicals is crucial to the effective manipulation of biological control agents (BCAs). The attraction specificity can also be improved by combining volatile compounds in blends (Rodriguez-Saona et al., 2012). 


\subsection{Farmers and the use of alternative methods}

Farmers do not always greet the suggestion of using alternative methods with much enthusiasm, especially those on small-scale farms or in developing countries (Gozzo et al., 2013; Bashan et al., 2014). They tend not to adopt biostimulant products or innovative crop protection strategies unless their success is guaranteed. The highest number of farmers currently using biobased products, which include plant biostimulants and biopesticides, is in North America, representing $40 \%$ of the biocontrol market, compared with $25 \%$ in Europe, $20 \%$ in Asia, 10\% in South America and 5\% in the rest of the world (Cox et al., 2013).

The main reason for farmer skepticism about these alternative methods relates to their variable efficacy in the field compared with conventional chemical inputs (Arora et al., 2010; Walters et al., 2013). Many studies have shown that these products can have a variable field performance, in contrast to the promising results obtained in the laboratory or in greenhouse conditions (Gozzo et al., 2013). There are several reasons for this inconsistency in practical conditions.

In the case of PGPR, bacteria concentrations in commercialized products can fall below the desired threshold (usual concentration: $10^{8}-10^{11}$ cells $\cdot \mathrm{ml}^{-1}$ ), especially under long-term or inadequate storage (Bashan et al., 2014). A less effective interaction can also occur when the PGPR inoculant is not adapted to the host plant or the local environmental conditions (climate, soil characteristics, agronomic practices). For example, modern rice varieties selected to use $\mathrm{N}$ fertilizers effectively are less interactive with native $\mathrm{N}$-fixing bacteria than traditional varieties (Araújo et al., 2013). Similarly, the performance of elicitors depends greatly on field environmental conditions (temperature, relative humidity, disease pressure), crop systems (plant genotype, nutritional requirements, physiological state) and the formulation (Walters et al., 2014).

Farmers' decisions on whether or not to adopt new methods often depend on how much they want to change their agricultural practices. Total reliance on new strategies can be challenging. The benefits of these strategies have to be clearly demonstrated through educational programs that focus on field data (e.g. pest/disease identification, timing of infestation, crops) (Rodriguez-Saona et al., 2009). This includes detailed knowledge about agronomic parameters and designing adapted crop management techniques, with the appropriate biostimulant or biocontrol product applied at the right time and frequency, in combination with other control methods and on responsive cultivars (Walters et al., 2013; Bashan et al., 2014).

Henceforth, tools need to be designed that meet farmers' demands by ensuring: optimal crop yield with lower input costs; compatibility between the applied products and soil conditions, farming machines and equipment; and good shelf life and long-term survival during storage, especially with PGPR inoculants (Bashan et al., 2014). The integration of biostimulant and biocontrol products into agricultural practices depends on their economic relevance compared with conventional practices (Rodriguez-Saona et al., 2012; Bashan et al., 2014; Walters et al., 2014). Currently, apart from open field applications, biocontrol techniques are widely and efficiently used in the pre- and post-harvest treatments of specific product lines, such as horticultural and ornamental crops (e.g., cucumber, lettuce, cyclamen, roses) (Darras, 2012). Further research is needed on improving the understanding of which field conditions are most suited to the use of a specific biostimulant or biocontrol product (Bhattacharyya et al., 2012; Walters et al., 2013). Scientists are aware of the stakes involved here and many partnerships have been launched. In France, an integrated network called Elicitra was created in 2011 with the aim of promoting the strategy of plant induced resistance by elicitors through research, training and development (Bazinet, 2012). This network includes partners from public research bodies, technical institutes, crop industries and universities. Partners in the network include Arvalis-Plant Institute and the French National Institute for Agricultural Research (INRA). The successful integration of biostimulants and biocontrol products into plant health care programs is generally ensured by trials carried out by such institutions. Similarly, a European stakeholders association, the European Biostimulants Industry Council (EBIC), was founded in 2011 and provides technical and practical information on plant biostimulants (Traon et al., 2014).

\subsection{Regulatory framework}

Alarge number of biostimulant and biocontrol products, that have long been known and have been patented for agricultural plant growth-promotion and/or pest management, are still not available commercially in the EU, unlike the situation in other countries in the world (Dayan et al., 2009). Many products that encourage plant growth or plant protection have not been registered and there is a lack of fit-for-purpose regulatory procedures in the EU because of the time and costs of registration (Arora et al., 2010; Köhl, 2010; Walters et al., 2014). The approval of any Plant Protection Product (PPP) requires the registration of the active material on a list validated by the EU (European Parliament, 2009b).

In the case of biostimulants, these products are still not covered by EU regulatory procedures and need to be included in the framework of PPP products. 
The Fertilizers Regulation 2003/2003 covers only the placing of inorganic fertilizers (EC fertilisers) on the market and has been under revision since 2012-2013, with the aim of extending its scope to other fertilizing and related materials, such as plant biostimulants and fertilizer additives (Traon et al., 2014).

The legal aspects related to using semiochemicals are also complicated. Semiochemicals are regulated as a group of biopesticides (i.e. active substances used for plant protection that are of natural origin or are nature-identical synthetic substances) (Chandler et al., 2011). In the EU, biopesticides are subject to the same registration procedure as synthetic pesticides, but new guidelines facilitating their registration process are being developed (Czaja et al., 2015). The status of biopesticides was established in Regulation 1095/2007 (Commission Regulation, 2007). It allows the insertion into Regulation 540/2011 of active substances that do not have a harmful impact on human and animal health, or a negative environmental impact. Each substance has to comply with strict criteria, listed in Annex IV of Regulation 1095/2007, in order to be considered safe (Commission Implementing Regulation, 2011).

The current strategy of the EU in sustaining the development of new biostimulant and biocontrol methods in agriculture is implemented via various legislative procedures. Regulation 1107/2009 aims to harmonize the overall procedures authorizing plant protection products in the EU market. It also facilitates approval of natural substances (Article 23), thereby simplifying the regulation procedures for natural preparations with low risk. The EU has recently proposed granting the first approvals for agrochemicals in a new category entitled "basic substances". In addition, Directive 2009/128/EC regulates the sustainable use of pesticides in Europe: "Member States shall take all necessary measures to promote low pesticide-input pest management, giving wherever possible priority to non-chemical methods, so that professional users of pesticides switch to practices and products with the lowest risk to human health and the environment among those available for the same pest problem" (European Parliament, 2009a).

In 2008, France announced its Ecophyto2018 plan, which aims to reduce pesticide use by $50 \%$ by 2018 , mainly through the identification and development of bioactive compounds able to stimulate plant immunity (Information Réglementaire Ecophyto-2018, 2011). The reduction of conventional inputs is also planned in other European countries, including Belgium (NAPAN, 2013), Germany (National Action Plan on Sustainable Use of Plant Protection Products, 2013) and the UK (UK NAP, 2013). The promise of strong growth in the biocontrol market in a near future has also led major agrochemical companies to invest in these green technologies. All stakeholders in the agricultural sector, including agricultural distributors and plant breeders, could play an important role in promoting the use of biostimulant and biocontrol products.

\section{CONCLUSIONS AND PERSPECTIVES}

Strong efforts are being made to improve attitudes in the farming community, and in society in general, towards the use of alternative methods to chemical inputs. It is widely agreed that PGPR biostimulants, elicitors and semiochemicals should not be used as stand-alone methods in agroecological management, but integrated into fertilization and disease/pest control strategies to complement chemical inputs and contribute to a reduction in their dosage amounts and application frequency. Although these tools have been widely endorsed for their advantages, farmers and growers are still not completely confident about using them, mainly because of their fluctuating field performance (Beckers et al., 2007). Farmers need more information on how to use these tools in their agricultural practices. Regulators, investors, growers and consumers also need to be well informed about the advantages of these alternative methods and their potential in promoting sustainable agriculture.

Further research is needed to better understand the environmental parameters affecting the efficiency of these products, particularly for field crops. Special attention should also be given to the formulation and the potential interactions of these products with the plant environment. Multidisciplinary research groups, such as the AgricultureIsLife platform (Gembloux Agro-BioTech, Université de Liège, Belgium), should address the question of how best to use these tools, given current practices, by studying the issues that still need to be overcome (e.g. screening methodology, formulation, environmental impact).

Many challenges remain before biostimulant and biocontrol products can be widely and successfully used on a commercial basis, but the intensive efforts in research and the legislative area, as well as in enhancing society's awareness of these products, will increase their credibility and acceptance (Wezel et al., 2014). Agricultural practices using these tools need to be adapted (e.g. using cultivars specifically chosen for the appropriate responses) (Walters et al., 2014). In Europe, the long-term objective to be pesticide free is already leading to changes in crop management practices and represents a major driver in the use of biostimulant and biocontrol products. Within the context of climate change, increasing environmental concerns and population increase, these alternative methods offer important potential tools for achieving sustainable food production. 


\section{Acknowledgements}

We thank the University of Liège - Gembloux Agro-Bio Tech and more specifically the research platform AgricultureIsLife for the funding of this research project.

\section{Bibliography}

Adesemoye A., Torbert H. \& Kloepper J., 2009. Plant growthpromoting rhizobacteria allow reduced application rates of chemical fertilizers. Microb. Ecol., 58(4), 921929.

Araújo A.E.D.S. et al., 2013. Response of traditional upland rice varieties to inoculation with selected diazotrophic bacteria isolated from rice cropped at the northeast region of Brazil. Appl. Soil Ecol., 64, 49-55.

Arora N.K., Khare E. \& Maheshwari D.K., 2010. Plant growth promoting rhizobacteria: constraints in bioformulation, commercialization, and future strategies. In: Maheshwari D.K., ed. Plant Growth and Health Promoting Bacteria. Dordrecht, The Netherlands: Springer.

Bashan Y. et al., 2014. Advances in plant growth-promoting bacterial inoculant technology: formulations and practical perspectives (1998-2013). Plant Soil, 378(1-2), $1-33$.

Bazinet C., 2012. ELICITRA, http://elicitra.org/, (04.08. 2014).

Beckers G.J. \& Conrath U., 2007. Priming for stress resistance. Curr. Opin. Plant Biol., 10(4), 425-431.

Bhattacharyya P. \& Jha D., 2012. Plant growth-promoting rhizobacteria (PGPR): emergence in agriculture. World J. Microbiol. Biotechnol., 28(4), 1327-1350.

Boller T. \& Felix G., 2009. A renaissance of elicitors: perception of microbe-associated molecular patterns and danger signals by pattern-recognition receptors. Аnnu. Rev. Plant Biol., 60, 379-407.

Çakmakçi R. et al., 2014. Rhizobacteria for reduced fertilizer inputs in wheat (Triticum aestivum spp. vulgare) and barley (Hordeum vulgare) on Aridisols in Turkey. Int. J. Plant Prod., 8(2), 163-181.

Calvo P., Nelson L. \& Kloepper J., 2014. Agricultural uses of plant biostimulants. Plant Soil., 383(1), 3-41.

Cardé R., 2007. Using pheromones to disrupt mating of moth pests. In: Kogan M. \& Jepson P., eds. Perspective in ecological theory and integrated pest management. Cambridge University Press, 122-169.

Chandler D. et al., 2011. The development, regulation and use of biopesticides for integrated pest management Philos. Trans. R. Soc. B, 366(1573), 1987-1998.

Chowdhury S.P. et al., 2013. Effects of Bacillus amyloliquefaciens FZB42 on lettuce growth and health under pathogen pressure and its impact on the rhizosphere bacterial community. PLOS ONE, 8(7).

Commission Implementing Regulation, 2011. Commission implementing Regulation (EU) No 540/2011 of 24 May
2011 implementing Regulation (EU) No 1107/2009 of the European Parliament and of the Council as regards the list of approved active substances, http://eur-lex. europa.eu/LexUriServ/LexUriServ.do?uri=OJ:L:2011: 153:0001:0186:EN:PDF, (04.08.2014).

Commission Regulation, 2007. Commission Regulation (EC) No 1095/2007 of 20 September 2007 amending Regulation (EC) No 1490/2002 laying down further detailed rules for the implementation of the third stage of the programme of work referred to in Article 8(2) of Council Directive 91/414/EEC and Regulation (EC) No 2229/2004 laying down further detailed rules for the implementation of the fourth stage of the programme of work referred to in Article 8(2) of Council Directive 91/414/EEC, http://www.pesticides.gov.uk/ Resources/CRD/Migrated-Resources/Documents/C/ Commission_Regulation_1095_2007.pdf, (06.01.2015).

Cook S.M., Khan Z.R. \& Pickett J.A., 2007. The use of push-pull strategies in integrated pest management. Annu. Rev. Entomol., 52, 375.

Cox M. \& Wong B., 2013. Biological crop chemistry primer: green shoots through green products, PiperJaffray industry note, http://library.constantcontact. com/download/get/file/1102591137375-215/ Cox+Industry+Note+-+Agriculture+08.27.13+copy.pdf, (06.01.2015).

Czaja K. et al., 2015. Biopesticides - towards increased consumer safety in the European Union. Pest Manage. Sci., 71, 3-6.

Darras A.I., 2012. Novel elicitors induce defense responses in cut flowers. In: Cumagun C.J., ed. Plant pathology. Rijeka, Croatia: InTech.

Dayan F.E., Cantrell C.L. \& Duke S.O., 2009. Natural products in crop protection. Bioorg. Med. Chem., 17(12), 4022-4034.

du Jardin P., 2012. The science of plant biostimulants - a bibliographic analysis, http://ec.europa.eu/enterprise/ sectors/chemicals/files/fertilizers/final_report_ bio_2012_en.pdf, (07.14.2015).

European Biostimulants Industry Consortium, 2011. Position on the revision of Reg (EC) 2003/2003, http://www. biostimulants.eu/wp-content/uploads/2011/12/EBIC_ Position_7Options_29Nov2011.pdf, (07.14.2015).

European Commission EGTOP, 2011. Final report on plant protection products, http://ec.europa.eu/ agriculture/organic/eu-policy/expert-advice/documents/ final-reports/final_report_egtop_on_plant_protection_ products_en.pdf, (07.14.2015).

European Commission, 2012. Sustainable agriculture for the future we want, http://ec.europa.eu/agriculture/ events/2012/rio-side-event/brochure_en.pdf, $\quad$ (06.01. 2015).

European Parliament, 2009a. Directive 2009/128/EC of the European Parliament and of the Council of 21 October 2009 establishing a framework for Community action to achieve sustainable use of pesticides, http://eur-lex. 
europa.eu/LexUriServ/LexUriServ.do?uri=OJ:L:2009:3 09:0071:0086:en:PDF, (04.08.2014).

European Parliament, 2009b. Regulation (EC) No 1107/2009 of the European Parliament and of the Council of 21 October 2009 concerning the placing of plant protection products on the market and repealing Council Directives 79/117/EEC and 91/414/ EEC, http://eur-lex.europa.eu/legal-content/EN/TXT/ $\mathrm{PDF} /$ ?uri=CELEX:02009R1107-20130701\&rid=1, (04.08.2014).

García-Mier L. et al., 2013. Agriculture and bioactives: achieving both crop yield and phytochemicals. Int. J. Mol. Sci., 14, 4203-4222.

Gozzo F. \& Faoro F., 2013. Systemic acquired resistance ( 50 years after discovery): moving from the lab to the field. J. Agric. Food Chem., 61, 12473-12491.

Henry G., 2013. Study of the induced systemic resistance of plants: molecular aspects of the interaction between plant cells and amphiphilic elicitors produced by non-pathogenic rhizobacteria. $\mathrm{PhD}$ thesis: Université de Liège - Gembloux Agro-Bio Tech, Gembloux (Belgium).

Henry G., Thonart Ph. \& Ongena M., 2012. PAMPs, MAMPs, DAMPs and others: an update on the diversity of plant immunity elicitors. Biotechnol. Agron. Soc. Environ., 16(2), 257-268.

Herth A.,2011.Lebio-contrôlepourlaprotectiondescultures : 15 recommandations pour soutenir les technologies vertes, http://www.ladocumentationfrancaise.fr/var/ storage/rapports-publics/114000224.pdf, (07.14.2015).

Heuskin S. et al., 2011. The use of semiochemical slowrelease devices in integrated pest management strategies. Biotechnol. Agron. Soc. Environ., 15(3), 459-470.

Hol G.W.H., Bezemer M.T. \& Biere A., 2013. Getting the ecology into interactions between plants and the plant growth-promoting bacterium Pseudomonas fluorescens. Front. Plant Sci., 4.

Information Réglementaire Ecophyto 2018, 2011. Information Réglementaire Ecophyto2018: de nouveaux textes pour sécuriser et diminuer l'utilisation de produits phytopharmaceutiques, http://agriculture.gouv.fr/tel echarger/36425?token $=$ d00ad843ed4f7e $8 \mathrm{a} 30 \mathrm{af} 796 \mathrm{f}$ $5 \mathrm{~d} 68 \mathrm{c} 200 \mathrm{forme}$ agrement_certificat-individuel.pdf, (16.11.2015).

Islam F. et al., 2014. Influence of Pseudomonas aeruginosa as PGPR on oxidative stress tolerance in wheat under $\mathrm{Zn}$ stress. Ecotoxicol. Environ. Saf., 104(1), 285-293.

Jones J.D.G. \& Dangl J.L., 2006. The plant immune system. Nature, 444(7117), 323-329.

Khan Z.R., Pickett J.A., Wadhams L. \& Muyekho F., 2001. Habitat management for the control of cereal stemborers and Striga in maize in Kenya. Insect Sci. Appl., 21, 375380.

Khan Z.R. \& Pickett J.A., 2004. The "Push-Pull" strategy for stemborer management: a case study in exploiting biodiversity and chemical ecology. In: Gurr G.,
Wratten S.D.\&Altieri M.A.,eds.Ecological engineering for pest management: advances in habitat manipulation for arthropods. Oxfordshire: CABI Publishing, 155-164.

Kilian M. et al., 2000. FZB24® Bacillus subtilis - mode of action of a microbial agent enhancing plant vitality. Pflanzenschutz-Nachr. Bayer, 53(1), 72-93.

Köhl J.,2010. Microbials: the need for a pragmatic approach. New Ag Int., September, 34-42.

Kröber M. et al., 2014. Effect of the strain Bacillus amyloliquefaciens FZB42 on the microbial community in the rhizosphere of lettuce under field conditions analyzed by whole metagenome sequencing. Front. Microbiol., 5, 252.

Mäder P. et al., 2011. Inoculation of root microorganisms for sustainable wheat-rice and wheat-black gram rotations in India. Soil Biol. Biochem., 43, 609-619.

Marks B.B. et al., 2013. Biotechnological potential of rhizobial metabolites to enhance the performance of Bradyrhizobium spp. and Azospirillum brasilense inoculants with soybean and maize. AMB Express, 3 , $1-10$.

Mejía-Teniente L. et al., 2010. Use of elicitors as an approach for sustainable agriculture. Afr. J. Biotechnol., 9(54), 9155-9162.

Mendes R. et al., 2011. Deciphering the rhizosphere microbiome for disease-suppressive bacteria. Science, 332(6033), 1097-1100.

NAPAN, 2014. Belgian action plan to reduce the risks and impacts linked to pesticides 2013-2017, http:// documentatie.leefmilieubrussel.be/documents/plan belgian_pesticides_en.PDF?langtype=2067, $\quad(07.15$. 2015).

National Action Plan on Sustainable Use of Plant Protection Products, 2013. National Action Plan on Sustainable Use of Plant Protection Products, http://ec.europa.eu/ food/plant/pesticides/sustainable_use_pesticides/docs/ nap_germany_en.pdf, (07.15.2015).

Pérez-Montaño F. et al., 2013. Plant growth promotion in cereal and leguminous agricultural important plants: from microorganism capacities to crop production. Microbiol. Res., 169, 325-336.

Pichersky E. \& Gershenzon J., 2002. The formation and function of plant volatiles: perfumes for pollinator attraction and defense. Curr. Opin. Plant Biol., 5(3), 237-243.

Reddy M.V.B. et al., 1999. Chitosan treatment of wheat seeds induces resistance to Fusarium graminearum and improves seed quality. J. Agric. Food Chem., 47(3), 1208-1216.

Reddy P.P., 2014. Plant growth promoting rhizobacteria for horticultural crop protection. New Delhi: Springer.

Rodriguez-Saona C.R. \& Stelinski L.L., 2009. Behaviormodifying strategies in IPM: theory and practice. In: Peshin R. \& Dhawan A.K., eds. Integrated pest management: innovation-development process. The Nederlands: Springer, 263-315. 
Rodriguez-Saona C. et al., 2011. Field responses of predaceous arthropods to methyl salicylate: a metaanalysis and case study in cranberries. Biol. Control, 59(2), 294-303.

Rodriguez-Saona C., Blaauw D. \& Isaacs R., 2012. Manipulation of natural enemies in agroecosystems: habitat and semiochemicals for sustainable insect pest control. In: Marcelo L.L. \& Soloneski S., eds. Integrated pest management and pest control - current and future tactics. Rijeka, Croatia: InTech, 89-126.

Schwessinger B. \& Ronald P.C., 2012. Plant innate immunity: perception of conserved microbial signatures. Annu. Rev. Plant Biol., 63, 451-482.

Simwinga E., Mukuka R. \& Kamwale H., 2010. The use of TwinN (nitrogen fixing bacteria for non legumes) as an alternative source of nitrogen for sugarcane production. In: S.A.S.T. Association, ed. Proceedings of the South African Sugar Technologists' Association annual general meeting and congress, 83, 221-224.

Sobhy I.S. et al., 2012. Less is more: treatment with BTH and laminarin reduces herbivore-induced volatile emissions in maize but increases parasitoid attraction. J. Chem. Ecol., 38(4), 348-360.

Tajini F., Trabelsi M. \& Drevon J.J., 2012. Combined inoculation with Glomus intraradices and Rhizobium tropici CIAT899 increases phosphorus use efficiency for symbiotic nitrogen fixation in common bean (Phaseolus vulgaris L.). Saudi J. Biol. Sci., 19(2), 157-163.

Tállai M. et al., 2012. Comparative examination of a bacterium preparation (Bactofil $\left.{ }^{\circledR} \mathrm{A} 10\right)$ and an artificial fertilizer $\left[\mathrm{Ca}\left(\mathrm{NO}_{3}\right)_{2}\right]$ on humic sandy soil. Ann. Univ. Oradea Fascicula Protectia Mediului, 18, 81-88.

Traon D. et al., 2014. A legal framework for plant biostimulants and agronomic fertiliser additives in the EU - Report to the European Commission, Enterprise \& Industry Directorate - General. Brussels: Arcadia International.

UK NAP, 2013. UK National action plan for the sustainable use of pesticides (plant protection products), http://cipm.org/fileadmin/c-ipm.org/British_NAP__in_EN_. pdf, (07.15.2015).

Upadhyay S.K. \& Singh D.P., 2015. Effect of salt-tolerant plant growth-promoting rhizobacteria on wheat plants and soil health in a saline environment. Plant Biol., 17(1), 288-293.

Vallad G.E. \& Goodman R.M., 2004. Systemic acquired resistance and induced systemic resistance in conventional agriculture. Crop Sci., 44(6), 1920-1934.

Vet L.E.M. \& Dicke M., 1992. Ecology of infochemical use by natural enemies in a tritrophic context. Annu. Rev. Entomol., 37, 141-172.

Walker V. et al., 2012. Variation of secondary metabolite levels in maize seedling roots induced by inoculation with Azospirillum, Pseudomonas and Glomus consortium under field conditions. Plant Soil, 356(1-2), 151-163.

Walters D.R., Ratsep J. \& Havis N.D., 2013. Controlling crop diseases using induced resistance: challenges for the future. J. Exp. Bot., 64(5), 1263-1280.

Walters D.R., Newton A.C.\& Lyon G.D.,eds, 2014.Induced resistance for plant defense: a sustainable approach to crop protection. $2^{\text {nd }}$ ed. Oxford, UK: Wiley-Blackwell.

Wasternack C. \& Hause B., 2013. Jasmonates: biosynthesis, perception, signal transduction and action in plant stress response, growth and development. An update to the 2007 review in Annals of Botany. Ann. Bot., 111(6), 1021-1058.

Wezel A. et al., 2014. Agroecological practices for sustainable agriculture. A review. Agron. Sustain. Dev., 34(1), 1-20.

Witzgall P., ed., 2001. Pheromones and other biological techniques for insect control in orchards and vineyards. Working group "Use of pheromones and other semiochemicals in integrated control", Proceedings of the meeting in Hohenheim (Baden-Württemberg, Germany), 10-12 November, 1999. IOBC/wprs Bull., 24(2).

Worrall D. et al., 2012. Treating seeds with activators of plant defence generates long-lasting priming of resistance to pests and pathogens. New Phytol., 193(3), 770-778.

Yao A.V. et al., 2006. Effect of FZB 24® Bacillus subtilis as a biofertilizer on cotton yields in field tests. Arch. Phytopathol. Plant Prot., 39(4), 323-328.

(72 ref.) 
Appendix 1. Examples of promising plant growth-promoting rhizobacteria (PGPR)-based biostimulants for the reduction of chemical fertilizers under various experimental conditions - Exemples de biostimulants prometteurs à base de rhizobactéries promotrices de la croissance des plantes (PGPR), pour une réduction de l'usage des fertilisants chimiques dans des conditions d'expérimentations variées.

\begin{tabular}{|c|c|c|c|c|}
\hline Biostimulant & $\begin{array}{l}\text { Enhancement of crop growth and } \\
\text { reduction of chemical fertilizer } \\
\text { level }\end{array}$ & Crop & $\begin{array}{l}\text { Experimental } \\
\text { conditions }\end{array}$ & Reference \\
\hline $\begin{array}{l}\text { Bacillus megaterium M3, } \\
\text { Bacillus OSU-142, } \\
\text { Azospirillum brasilense sp. } \\
\text { 245, Paenibacillus polymyxa } \\
\text { RC05, Bacillus megaterium } \\
\text { RC07, Bacillus licheniformis } \\
\text { RC08, Raoutella terrigena, } \\
\text { Burkholderia cepacia } \text { FS Tur }\end{array}$ & $\begin{array}{l}\text { Plant root and shoot weight increase } \\
\text { under greenhouse conditions. Single } \\
\text { and combinations of PGPR increased } \\
\text { yield up to } 40.4 \% \text { for wheat and } \\
33.7 \% \text { for barley under field } \\
\text { conditions and in combination with } \\
\mathrm{N} \text { fertilizer }\end{array}$ & Wheat, barley & $\begin{array}{l}\text { Greenhouse } \\
\text { and field }\end{array}$ & $\begin{array}{l}\text { Çakmakçi et al., } \\
2014\end{array}$ \\
\hline Pseudomonas aeruginosa & $\begin{array}{l}\text { Improved } \mathrm{N} \text { and } \mathrm{P} \text { uptake. Increase } \\
\text { in leaf chlorophyll amounts and } \\
\text { plant biomass under } \mathrm{Zn} \text { stress } \\
\text { (enhancement of antioxidative } \\
\text { enzymes, ascorbic acid and total } \\
\text { phenolics) }\end{array}$ & Wheat & Greenhouse & $\begin{array}{l}\text { Islam et al., } \\
2014\end{array}$ \\
\hline $\begin{array}{l}\text { Arthrobacter sp. and } \\
\text { Bacillus subtilis }\end{array}$ & $\begin{array}{l}\text { Increased plant tolerance to salinity. } \\
\text { Plant dry weight increased up to } 26 \% \\
\text { and } 40 \% \text { under } 2 \mathrm{dS} \cdot \mathrm{m}^{-1} \text { and } 6 \mathrm{dS} \cdot \mathrm{m}^{-1} \\
\text { salinity level, respectively }\end{array}$ & Wheat & Greenhouse & $\begin{array}{l}\text { Upadhyay et al., } \\
2015\end{array}$ \\
\hline $\begin{array}{l}\text { Burkholderia vietnamiensis } \\
\text { AR112 }\end{array}$ & $\begin{array}{l}\text { Increased or equivalent weight and } \\
\text { yield of traditional rice compared } \\
\text { with } 100 \% \mathrm{~N} \text { chemical fertilization }\end{array}$ & Rice & Field & $\begin{array}{l}\text { Araújo et al., } \\
2013\end{array}$ \\
\hline $\begin{array}{l}\text { Bradyrhizobium spp. and } \\
\text { concentrated metabolites from } \\
\text { Bradyrhizobium diazoefficiens }\end{array}$ & $\begin{array}{l}\text { Increased grain yield by } 4.8 \% \\
\text { compared with the exclusive use of } \\
\text { Bradyrhizobium spp. }\end{array}$ & Soybean & $\begin{array}{l}\text { Greenhouse } \\
\text { and field }\end{array}$ & $\begin{array}{l}\text { Marks et al., } \\
2013\end{array}$ \\
\hline $\begin{array}{l}\text { Rhizobium tropici CIAT } 899 \\
\text { Glomus intraradices }\end{array}$ & $\begin{array}{l}\text { Increase in } \mathrm{P} \text { and } \mathrm{N} \text { amounts up to } \\
40 \% \text { and } 42 \% \text {, respectively, in soil. } \\
\text { Nodule number enhanced by } 70 \% \\
\text { and nodule mass by } 43 \% \text {. Plant shoot } \\
\text { dry weight increased by up to } 24 \% \\
\text { and root growth by up to } 48 \%\end{array}$ & Bean & Greenhouse & $\begin{array}{l}\text { Tajini et al., } \\
2012\end{array}$ \\
\hline $\begin{array}{l}\text { Pseudomonas jessenii, } \\
\text { Pseudomonas synxantha } \\
\text { and a local AM }\end{array}$ & $\begin{array}{l}\text { PGPR or AMF alone increased yield } \\
\text { by up to } 29 \% \text { and } 31 \% \text {, respectively. } \\
\text { Combining PGPR and AMF } \\
\text { increased the yield by up to } 41 \%\end{array}$ & Wheat & Field & $\begin{array}{l}\text { Mäder et al., } \\
2011\end{array}$ \\
\hline $\begin{array}{l}\text { Bacillus amyloliquefaciens } \\
\text { IN937a, } \\
\text { Bacillus pumilus T4, } \\
\text { Glomus intraradices }\end{array}$ & $\begin{array}{l}\text { Inoculation of PGPR and AM } \\
\text { together reduced fertilizer use by } \\
25 \% \text {. Combination was equivalent to } \\
100 \% \text { fertilizer application for plant } \\
\text { growth, yield and nutrient uptake }\end{array}$ & Tomato & Greenhouse & $\begin{array}{l}\text { Adesemoye } \\
\text { et al., } 2009\end{array}$ \\
\hline Bacillus subtilis & $\begin{array}{l}\text { Plant growth and yield enhanced } \\
\text { by up to } 30 \% \text { compared with NPK } \\
\text { fertilization }\end{array}$ & Cotton & Field & Yao et al., 2006 \\
\hline
\end{tabular}


Appendix 2. Examples of commercialized PGPR-based products in Europe, North America and Asia - Exemples de produits à base de rhizobactéries promotrices de la croissance des plantes, actuellement commercialisés en Europe, en Amérique du Nord et en Asie.

\begin{tabular}{|c|c|c|c|}
\hline Products & Rhizobacteria & Crop & Manufacturer \\
\hline Amase $\AA$ & Pseudomonas azotoformans & \multirow[b]{2}{*}{$\begin{array}{l}\text { Cucumber, lettuce, tomato, } \\
\text { pepper }\end{array}$} & Lantmannen Bioagri, Sweden \\
\hline AmniteA100® & $\begin{array}{l}\text { Azotobacter, Bacillus, } \\
\text { Pseudomonas, Rhizobium, } \\
\text { Chaetomium }\end{array}$ & & Cleveland Biotech, UK \\
\hline BactoFil A10® & $\begin{array}{l}\text { Azospirillum brasilense, } \\
\text { Azotobacter vinelandii, } \\
\text { B. megaterium, B. polymyxa, } \\
\text { P. fluorescens }\end{array}$ & Monocotyledons (cereals) & \multirow{2}{*}{$\begin{array}{l}\text { AGRO.bio Hungary Kft., } \\
\text { Hungary }\end{array}$} \\
\hline BactoFil B10® & $\begin{array}{l}\text { Azospirillum lipoferum, } \\
\text { Azotobacter vinelandii, } \\
\text { B. megaterium, B. circulans, } \\
\text { B. subtilis, P.fluorescens }\end{array}$ & $\begin{array}{l}\text { Dicotyledons (sunflower, } \\
\text { potato, rapeseed) }\end{array}$ & \\
\hline Cérès® & Pseudomonas fluorescens & Field and horticultural crops & Biovitis, France \\
\hline Compete $\AA$ Plus & $\begin{array}{l}\text { B. azotofixans, B. licheniformis, } \\
\text { B. megaterium, B.polymyxa, } \\
\text { B. pumilus, B. subtilis }\end{array}$ & Field crops, tree nurseries & Plant Health Care, USA \\
\hline FZB24®fl & $\begin{array}{l}\text { B. amyloliquefaciens ssp. } \\
\text { plantarum }\end{array}$ & Ornamentals, vegetables & \multirow[t]{2}{*}{ ABiTEP GmbH, Germany } \\
\hline Rhizovital 42® & B. amyloliquefaciens & Field crops & \\
\hline Gmax@ PGPR & $\begin{array}{l}\text { Azotobacter, Phosphobacteria, } \\
\text { P. fluorescens }\end{array}$ & Field crops & Greenmax AgroTech, India \\
\hline Inómix $®$ Biostimulant & $\begin{array}{l}\text { B. polymyxa }(\mathrm{IAB} / \mathrm{BP} / 01) \text {, } \\
\text { B. subtilis (IAB/BS/F1) }\end{array}$ & \multirow{3}{*}{ Cereals } & \multirow{3}{*}{ IAB (Iabiotec), Spain } \\
\hline Inómix $®$ Biofertilisant & $\begin{array}{l}\text { B. megaterium, Saccharomyces } \\
\text { cerevisiae, Azotobacter vinelandii, } \\
\text { Rhizobium leguminosarum }\end{array}$ & & \\
\hline Inómix $®$ phosphore & $\begin{array}{l}\text { P. fluorescens, B. megaterium, } \\
\text { Saccharomyces cerevisiae }\end{array}$ & & \\
\hline Micosat F® Uno & $\begin{array}{l}\text { Agrobacterium radiobacter AR } 39 \text {, } \\
\text { B. subtilis } \mathrm{BA} 41 \text {, } \\
\text { Streptomyces spp. SB } 14\end{array}$ & Fruits, vegetables, flowers & \multirow[b]{2}{*}{ CCS Aosta Srl, Italy } \\
\hline Micosat F® Cereali & $\begin{array}{l}\text { B. subtilis BR 62, } \\
\text { Paenibacillus durus PD } 76 \text {, } \\
\text { Streptomyces spp. ST } 60\end{array}$ & $\begin{array}{l}\text { Cereals, tomatoes, } \\
\text { sunflowers, beet, soybeans }\end{array}$ & \\
\hline Nitroguard $\AA$ & $\begin{array}{l}\text { Azospirillum brasilense NAB317, } \\
\text { Azorhizobium caulinodens NAB38, } \\
\text { Azoarcus indigens NAB04, } \\
\text { Bacillus sp. }\end{array}$ & \multirow{2}{*}{$\begin{array}{l}\text { Cereals, seed rape, sugar } \\
\text { beet, sugarcane, vegetables }\end{array}$} & \multirow{2}{*}{$\begin{array}{l}\text { Mapleton AgriBiotec Pty } \\
\text { Ltd, Australia }\end{array}$} \\
\hline TwinN $®$ & $\begin{array}{l}\text { Azospirillum brasilense NAB317, } \\
\text { Azorhizobium caulinodens NAB38, } \\
\text { Azoarcus indigens NAB04 }\end{array}$ & & \\
\hline PGA® & Bacillus sp. & Fruits, vegetables & Organica technologies, USA \\
\hline Rhizocell ® GC & B. amyloliquefaciens souche IT45 & Cereals & $\begin{array}{l}\text { Lallemand Plant Care, } \\
\text { Canada }\end{array}$ \\
\hline Symbion $®-N$ & $\begin{array}{l}\text { Azospirillum, Rhizobium, } \\
\text { Acetobacter, Azotobacter }\end{array}$ & \multirow{3}{*}{ Field crops, vegetables } & \multirow{3}{*}{$\begin{array}{l}\text { T. Stanes \& Company Ltd, } \\
\text { India }\end{array}$} \\
\hline Symbion $\AA-P$ & B. megaterium var. phosphaticum & & \\
\hline Symbion $\AA-K$ & Frateuria aurantia & & \\
\hline
\end{tabular}


Appendix 3. Examples of commercialized products with elicitor properties - Exemples de produits commercialisés et présentant des propriétés de stimulateurs de défenses naturelles des plantes.

\begin{tabular}{|c|c|c|c|c|}
\hline Products & Product origin & Crop & Disease Target & Manufacturer \\
\hline Vacciplant $(\mathbb{B}$ & $\begin{array}{l}\text { Laminarin extract } \\
\text { from brown algae } \\
\text { Laminaria digitata }\end{array}$ & $\begin{array}{l}\text { Apple orchards, tomato, } \\
\text { lettuce, cucumber, } \\
\text { strawberry, grapevine }\end{array}$ & $\begin{array}{l}\text { Powdery mildew, } \\
\text { downy mildew }\end{array}$ & $\begin{array}{l}\text { Laboratoire Goëmar, } \\
\text { France }\end{array}$ \\
\hline $\begin{array}{l}\text { Actigard } \AA / \text { Bion } ® \text { / } \\
\text { Blockade } \AA\end{array}$ & Acibenzolar-S-méthyl & Wheat, tomato & $\begin{array}{l}\text { Powdery mildew, } \\
\text { bacterial diseases }\end{array}$ & $\begin{array}{l}\text { Syngenta Crop } \\
\text { Protection, USA }\end{array}$ \\
\hline Elexa ${ }^{\circledR} 4$ PDB & Chitosan & $\begin{array}{l}\text { Grapevine, tomato, } \\
\text { potato, cucumber, field } \\
\text { crops }\end{array}$ & $\begin{array}{l}\text { Botrytis grey mould } \\
\text { (Botrytis cinerea), } \\
\text { powdery mildew, } \\
\text { downy mildew }\end{array}$ & $\begin{array}{l}\text { Plant Defense } \\
\text { Boosters Inc., USA }\end{array}$ \\
\hline Armour-Zen ${ }^{\circledR}$ & Chitosan & $\begin{array}{l}\text { Grapevine, } \\
\text { ornamentals }\end{array}$ & $\begin{array}{l}\text { Botrytis grey mould } \\
\text { (Botrytis cinerea), } \\
\text { white rot (Sclerotinia } \\
\text { sclerotiorum) }\end{array}$ & $\begin{array}{l}\text { Botry-Zen } 2010 \text { Ltd, } \\
\text { New Zealand }\end{array}$ \\
\hline Chitoplant $(\mathbb{R}$ & Chitosan & Tomato & Powdery mildew & $\begin{array}{l}\text { ChiProGmbH, } \\
\text { Germany }\end{array}$ \\
\hline Harp-N-Tek® & $\begin{array}{l}\text { Harpin protein from } \\
\text { the bacteria Erwinia } \\
\text { amylovara }\end{array}$ & $\begin{array}{l}\text { Apple and pear } \\
\text { orchards, grapevine, } \\
\text { tomato }\end{array}$ & $\begin{array}{l}\text { Apple and pear scab, } \\
\text { downy mildew }\end{array}$ & $\begin{array}{l}\text { Plant Health Care Inc., } \\
\text { USA }\end{array}$ \\
\hline Milsana® & $\begin{array}{l}\text { Ethanolic leaf extract } \\
\text { from giant knotweed } \\
\text { Reynoutria } \\
\text { sachalinensis }\end{array}$ & $\begin{array}{l}\text { Cucumber, strawberry, } \\
\text { tomato, wheat }\end{array}$ & Powdery mildew & $\begin{array}{l}\text { KHH BioScience, } \\
\text { USA ; BIOFA AG, } \\
\text { Germany }\end{array}$ \\
\hline Stifenia ${ }^{\circledR}$ & FEN 560 (Fenugrec) & Grapevine & Powdery mildew & S.O.F.T., France \\
\hline Helena Prophyt ${ }^{\circledR}$ & Potassium phosphite & $\begin{array}{l}\text { Field crops, vineyards, } \\
\text { orchards }\end{array}$ & $\begin{array}{l}\text { Downy mildew, purple } \\
\text { blotch (Alternaria } \\
\text { spp.), brown rot } \\
\text { (Monilia fructicola) }\end{array}$ & $\begin{array}{l}\text { Helena Chemical } \\
\text { Company, USA }\end{array}$ \\
\hline Aliette ${ }^{\circledR W G}$ & Fosetyl-Al & $\begin{array}{l}\text { Ornamental trees and } \\
\text { bushes, strawberry }\end{array}$ & Downy mildew & $\begin{array}{l}\text { Bayer Crop Science, } \\
\text { Germany }\end{array}$ \\
\hline
\end{tabular}

Adapted from Walters et al. (2014) - adapté de Walters et al. (2014). 
Appendix 4. Elicitors and the plant signaling pathways for induced resistance - Éliciteurs et voies de signalisation de la plante pour la résistance induite.

\section{INDUCED SYSTEMIC RESISTANCE (ISR)}

JA and ET signaling pathways



\section{SYSTEMIC ACQUIRED RESISTANCE (SAR)}

Pathogenic bacteria, fungi,
virus
Insects, herbivores $\rightarrow$ PAMPs
$\longrightarrow$ DAMPs

Chemicals

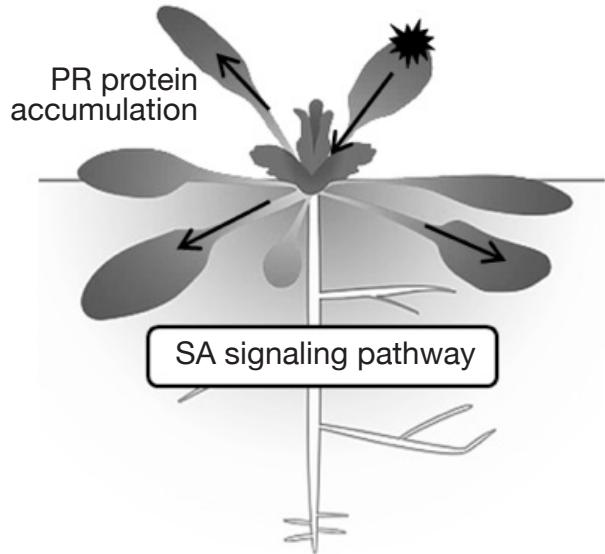

PGPR, PGPF, yeast, etc.

Various elicitor categories have been determined. Elicitors can belong to microbe-associated molecular patterns (MAMPs) emitted from non-pathogenic microorganisms such as plant growth-promoting rhizobacteria and fungi (PGPR, PGPF) or yeasts, and trigger induced systemic resistance (ISR) in the host plant through jasmonic acid (JA) and ethylene (ET) signaling pathways; Damage-associated molecular patterns (DAMPs) result from plant cell degradation after wounding by insects or herbivores; Pathogen-associated molecular patterns (PAMPs) are emitted from various pathogens. Chemicals such as Acibenzolar-S-methyl (ASM) and Probenazole, along with DAMPS and PAMPs, trigger systemic acquired resistance (SAR) in the plant through the salicylic acid (SA) signaling pathway, as well as the accumulation of pathogen-related (PR) proteins. The various signaling pathways cited here are non-exhaustive and other types of resistance can occur in the plant. There are comprehensive details on this in Jones et al. (2006) - Différentes catégories d'éliciteurs ont été caractérisées. Les éliciteurs peuvent faire partie des microbe-associated molecular patterns (MAMPs) émis par des micro-organismes non pathogènes tels que les rhizobactéries et champignons promoteurs de la croissance des plantes (PGPR, PGPF), ou des levures, et stimulent les systèmes de défenses de la plante sous forme d'une résistance systémique induite (ISR) via les voie de signalisation de l'acide jasmonique (JA) et de l'éthylène (ET) ; les damage-associated molecular patterns (DAMPs) résultent d'une dégradation de cellules végétales suite à une blessure infligée par un insecte ou un herbivore ; les pathogen-associated molecular patterns (PAMPs) sont émis par une variété d'agents pathogènes. Des substances chimiques telles que l'acibenzolar-S-methyl (ASM), le probénazole, ainsi que les DAMPS et PAMPs, stimulent une résistance systémique acquise dans la plante (SAR) via la voie de signalisation de l'acide salicylique (SA), tout en entrainant une accumulation de protéines $P R$ (pathogen-related) dans la plante. L'ensemble des voies de signalisation citées ici n'est pas une liste exhaustive et d'autres types de résistances peuvent intervenir au sein de la plante. D'excellents détails à ce sujet sont fournis dans les travaux de Jones et al.(2006). 